\title{
Grotius' book chest, international law and material culture
}

\author{
VALENTINA VADI* \\ Lancaster University Law School
}



'Book chest of Hugo de Groot, anonymous, c 1600-c 1615. Object Number NG-KOG-1208 Rijksmuseum (C) CC0 1.0 Universal $\dagger$

\begin{abstract}
What is the relationship between international law and material culture? This article argues that both material cultural studies and international legal scholarship can (and have) benefit(ed) from dialogue and mutual learning, and that such interaction has gradually become more and more explicit. Nevertheless, a traditional reticence remains, at least among international lawyers, about the merits of using material cultural in the theory and practice of international law. Therefore, the article illustrates the promises and pitfalls of the use of material culture in international legal scholarship and highlights that the use of material culture is as risky as it is promising.
\end{abstract}

Keywords: international law; material culture; paintings; temporary art; war.

* Professor of International Economic Law, Lancaster University Law School, v.vadi@lancaster.ac.uk. A version of this paper was presented at the Annual Conference of the Socio-Legal Studies Association, held at Newcastle University, on 6 April 2017. The author wishes to thank Diamond Ashiagbor, Amanda PerryKessaris, Sophie Vigneron, the anonymous reviewer and the participants at the conference for their comments on an earlier draft. The usual disclaimer applies. The research leading to these results has received funding from the European Research Council under a European Union (EU) European Research Council Starting Grant Agreement n 639564. The chapter reflects the author's views only and not necessarily those of the EU.

† <http://hdl.handle.net/10934/RM0001.COLLECT.53787> 


\section{Introduction}

Tisitors at the Rijksmuseum in Amsterdam are often startled by the book chest of Hugo Grotius (1583-1645), which is exhibited amidst the finest paintings of the Dutch golden age. Most visitors are not jurists let alone experts in international law or legal history. What they see is a rather simple wooden box encased in glass and located at the centre of a discretely large room. Yet, when international lawyers visit the museum, they inevitably gravitate toward the book chest. ${ }^{1}$ Once used for storing books, the large, solid box inexorably captures their imagination. ${ }^{2}$

Hugo Grotius is deemed to be one of the founders of international law. ${ }^{3}$ Considered 'the miracle of Holland', he wrote treatises which deeply influenced the development of international law as we know it. ${ }^{4}$ Imprisoned for his religious beliefs - as he was considered to be too 'Catholic' by the Reformers ${ }^{5}$ and too 'Protestant' by the Catholics 6 - he aptly escaped by hiding in a book chest, which his wife had sent to him while he was serving his prison sentence. ${ }^{7}$ While ambassador of Protestant Sweden in Catholic France, Grotius would later complete his major intellectual works, including the De Iure Belli ac Pacis (On the Law of War and Peace). ${ }^{8}$

The book chest of Hugo Grotius raises a number of interesting research questions. Usually considered as the evidence and the tool of an incredible escape, Grotius' book chest also shows that he was an erudite and avid reader. The existing letters that Grotius wrote to his relatives indicate that he managed to purposefully read specific books for writing his masterpiece, the De Iure Belli ac Pacis. ${ }^{9}$ Therefore, the book chest constitutes a visual clue that can contribute to ongoing investigations on early modern international law.

More fundamentally, the book chest also raises questions relating to the relationship between international law and material culture: that is, objects made or modified by human beings. ${ }^{10}$ Material culture is a broad concept, inclusive of artefacts as diverse as a

1 The book chest of Hugo Grotius is physically displayed in the Rijksmuseum, Amsterdam, and can be seen at <www.rijksmuseum.nl/en/rijksstudio/historical-figures/hugo-de-groot>.

2 When I visited the museum several years ago, the chest certainly captured my imagination. Admittedly, I did not speculate about the claustrophobic practical aspect of how one might have felt to have been shut up in it. Rather, I was pretty much captured by the adventurous dimension of Grotius' life and work and invested the trunk with special significance. The chest appeared as the promise of a new beginning, a symbol of resilience and success, and as an essential element in the history of international law. I now wonder whether the book chest can also constitute a powerful metaphor of international lawyers' personal struggles for the common good, or, as the anonymous reviewer suggested, the image of unveiling what is hidden, that is, truth.

3 But see James Brierly, The Law of Nations. An Introduction to the International Law of Peace (Clarendon Press 1963) 28 (noting that 'to consider Grotius as the founding father of international law is to exaggerate his originality and to do less than justice to the writers who preceded him').

4 Hedley Bull, 'The Importance of Grotius in the Study of International Relations', in Hedley Bull, Benedict Kingsbury and Adam Roberts (eds), Hugo Grotius and International Relations (Clarendon Press 1990) 65, 67.

5 C G Roelofsen, 'Grotius and the International Politics of the Seventeenth Century' in Bull et al (n 4) 95, 130 (noting that the Reformers perceived him as sympathising with the Catholics (Grotius Papizans)).

6 Henk J M Nellen, Hugo Grotius: A Lifelong Struggle for Peace in Church and State 1583-1645 (Brill 2014) 649 (noting that the Catholics considered Grotius as 'not Catholic enough' (non satis catholice)).

7 Bull (n 4) 68.

8 Grotius, De Iure Belli ac Pacis Libri Tres (first published 1625, F Kelsey (trans), Carnegie Foundation 1925).

9 On the relationship between Hugo Grotius and Alberico Gentili's writings, see Peter Haggenmacher, 'Il diritto della guerra e della pace di Gentili. Considerazioni sparse di un Groziano' in VV.AA. Il diritto della guerra e della pace di Alberico Gentili (Giuffré 1995) 9-54.

10 Jules David Prown, 'Mind in Matter: An Introduction to Material Culture Theory and Method' (1982) 17(1) Winterthur Portfolio 1-19, 1. 
chest, a vase, a painting, a house and a city. ${ }^{11}$ Artworks, such as paintings, sculpture, crafts, photography, film-making, literature and architecture, 'constitute a large and special category within artefacts because their . . . aesthetic and ... iconic dimensions make them direct and often ... intentional expressions of cultural belief'. ${ }^{12}$ The chest is a specimen of this category of material culture, an incredibly rich source of information and a thing through which to think reflect on international law.

Why should one investigate material culture in the study and/or making of international law? Is there anything to be discovered in objects that differ fromwhat can be learned from more traditional written sources? In addition to their cultural and sometimes iconic value, artefacts can have international legal relevance. They can be used as evidence for the study of international law. They can epitomise a significant event of international legal history, depicting the outbreak of a war, the making of a treaty or the consequences of war. They can also constitute the object (petitum) or the reason underlying a claimant cause of action (causa petendi) of given international disputes.

The interplay between international law and material culture raises important epistemological and methodological questions' about whether and, if so, how international lawyers might go about researching cultural artefacts that are relevant to their field. ${ }^{13}$ This article aims to open a discussion on the relevance of material culture in international law. It has an interdisciplinary nature, aiming to improve communication across international law and material culture studies and among different stakeholders, including international lawyers, art historians and the public at large.

The article proceeds as follows. First, it illustrates the promises of using material culture for studying and researching international law. Second, it examines the pitfalls of such an approach. After a critical assessment, it concludes that the traditional lack of reflection on the role of material culture in international law does not necessarily correspond to lack of relevance; on the contrary, international lawyers have engaged with material culture in a variety of ways.

\section{International law and material culture}

Material culture is an inclusive notion comprising objects made or modified by human beings. ${ }^{14}$ Material culture is a broad concept, encompassing artefacts as diverse as objects, buildings and even landscapes. ${ }^{15}$ Artworks - such as paintings, sculpture, crafts, photography, film-making, literature and architecture - are a special type of material culture because of their aesthetic and iconic value. ${ }^{16}$ Material culture has cultural and sometimes iconic value.

In certain cases, material culture can also have an international legal value. Objects such as photographs can (and have) be(en) used as evidence before international courts and tribunals. ${ }^{17}$ Material culture can epitomise a significant event of international legal

\footnotetext{
11 Ibid 2.

12 Ibid.

13 Sophie Woodward, 'Object Interviews, Material Imaginings and "Unsettling” Methods: Interdisciplinary Approaches to Understanding Materials and Material Culture’ (2016) 16 Qualitative Research 359, 360.

14 Prown (n 10) 1.

15 Ibid 2.

16 Ibid.

17 Daniel Joyce, 'Photography and the Image-Making of International Justice' (2010) 4 Law and Humanities 229,230 .
} 
history, depicting the outbreak of a war or the making of a treaty or other events of international relevance. It can also constitute the object (petitum) or the reason underlying a claimant cause of action (causa petendi) of given international law disputes. More fundamentally, it can 'shape international legal narratives and responses'. ${ }^{18}$

There are several benefits in using material culture for investigating international law. First, material culture can make international law more accessible to wider audiences. It can present complexity to the public in a way that is easy to understand. It can promote transparency, accountability and even an opportunity for self-reflection of international organisations, thus promoting the perceived legitimacy of such bodies. ${ }^{19}$ At the same time, material culture also opens new perspectives and raises new research questions, enabling international lawyers to consider international law from a different angle.

Second, the use of material culture can also have a pedagogical value, becoming a tool for building and sharing ideas. ${ }^{20}$ While law students are used to black letter textbooks, inserting some visual aid such as graphs, models and even pictures can help them make their discipline more concrete, challenging and interesting. Material culture can make international law accessible across disciplines; and among academic, practitioner and public audiences. Material culture can ' $\mathrm{ad}[\mathrm{d}]$ a whole new layer of learning that textbooks simply cannot provide'. ${ }^{21}$ Material culture 'can make abstract ideas . . come alive for students'.22

This approach is particularly promising for the study of international law. The material expansion of international law means that it governs almost any field of human activity and that it is therefore a key subject of study. Moreover, knowledge of international law is a condition of its respect. Fostering education about international law is a way to 'strengthe[n] international peace and security and promot[e] friendly relations and co-operation among States'. 23

Material culture can play an important role in teaching, disseminating and critically assessing international law. The interplay between material culture and international law can be a 'real eye-opener for many students', who may not perceive history or international law 'as engaging and ongoing (thus, needing to be thought about critically), but rather see it as a list of boring facts to be memorized'. ${ }^{24}$ Yet, scholars should be careful in maintaining objectivity. ${ }^{25}$

18 Ibid 231.

19 Ibid.

20 See e.g. Wouter Werner, 'Justice on Screen: A Study on Four Advocacy Documentaries on the ICC' (2016) 29 Leiden Journal of International Law 1034-60, 1034 (analysing four documentaries on the International Criminal Court and highlighting that 'Documentaries have thus become important tools for education and the spread of imageries of international criminal justice.').

21 Ernest Brewer and Penelope Fritzer, 'Teaching Students to Infer Meaning through Material Culture' (2011) 84 The Clearing House: A Journal of Educational Strategies, Issues and Ideas 43, 43.

22 Ibid 44.

23 Pierre D’Argent, 'Teachers of International Law' in Jean d'Aspremont, Tarcisio Gazzini, André Nollkaemper and Wouter Werner (eds), International Law as a Profession (Cambridge University Press 2017) 417.

24 Brewer and Fritzer (n 21) 45.

25 G Simpson, 'On the Magic Mountain: Teaching Public International Law' (1999) 10 European Journal of International Law 70, 91 (cautioning that international law should not be taught as 'the converse of a holiday brochure - brief illustrations from places we would not want to visit'); Martti Koskenniemi, 'International Law in Europe: Between Tradition and Renewal' (2005) 16 European Journal of International Law 113-24 (contending that '[i]nternational law is burdened by kitsch' and that the concept of jus cogens is an example of such kitsch, being expressed in 'a dead European language' with 'no clear reference to this world' but 'longing for such reference'). 
Third, material culture can also illuminate the state of the art, the promises and pitfalls of international law. Artists, reporters and the creators of visual data have become increasingly interested in representing complex social problems with international relevance. For instance, in a recent exhibition, Chinese artist Ai Wei Wei wrapped the Renaissance façade of Florence's Palazzo Strozzi in a series of red rubber life boats. Entitled Libero ('Free'), the exhibition drew attention to the fate of refugees often rescued by similar boats when they cross the Mediterranean Sea. The display of the red lifeboats on the façade of a patrician building - in the form of temporary art installation - sparked debate. ${ }^{26}$ While some critics contended that the installation of dinghies ruined the aesthetics of the city centre, others welcomed the initiative as a form of engaged artistic expression.

In another example, Banksy, a well-known yet anonymous British street artist, painted nine graffiti on the 425-mile-long barrier that separates Israel from the Palestinian territories. ${ }^{27}$ Allegedly built for security reasons, the wall has sparked controversy. ${ }^{28}$ While the International Court of Justice (ICJ) held that the wall was in breach of international law, ${ }^{29}$ the street artist transformed the same wall into a canvas for some of his/her most celebrated works. The graffiti can be interpreted in different ways. For instance, one portrays a little girl gently lifted by balloons toward the top of the wall. Filled with wit and metaphor, the graffiti transcend language barriers and seem to advocate a process of peace among the parties - and the maintenance of peace is one of the fundamental aims of international law. 30

International lawyers themselves can use material culture to illustrate the state of the art, the promises and pitfalls of international law. For instance, the cover illustration of a recent book, entitled International Law as a Profession, ${ }^{31}$ includes the visual reproduction of a painting, A Lawyer in his Study, by Adriaen Van Ostade (1610-1685). The painting depicts an old white-haired lawyer reading his files. The portrait expressly conveys the idea that (international) lawyers work long hours in shadowy workplaces. But the painting also implicitly illustrates the relative paucity and invisibility of women in the international law profession. ${ }^{32}$

Fourth, the iconography of warfare can contribute to show the dramatic consequences of war and indirectly cultivate a culture of peace. In the twentieth century, the British War Memorials Committee commissioned the American painter John Singer Sargent (1856-1925) to document an episode of chemical warfare during World War I. Although this was not Sargent's habitual terrain - most of his paintings portrayed members of the high society of the time - Sargent's oil on canvas titled Gassed-depicting a line of wounded and blindfolded men - struck a chord, won prizes and has become widely recognised as an embodiment of the pain of war'. ${ }^{33}$ Analogously, Pablo Picasso's

26 Steve Scherer, 'Boats Evoking Refugees Hang from Italy Palace in Ai Weiwei Installation', Reuters (London 22 September 2016).

27 Sam Jones, 'Spray Can Prankster Tackles Israel's Security Barrier', The Guardian (London 5 August 2005).

28 Nathaniel Berman, 'The Ambivalence of Walls in the Internationalist Imagination: Legal Scandal or the Foundation of Legal Order?' in Jean-Marc Sorel (ed), Les murs et le droit international (Pedone 2010).

29 ICJ, Legal Consequences of the Construction of a Wall in the Occupied Palestinian Territory (Advisory Opinion 9 July 2004) para. 163.

30 UN Charter, Article 1.1, United Nations, Charter of the United Nations, 24 October 1945, 1 UNTS XVI.

31 D'Aspremont et al (n 23).

32 Nienke Grossman, 'Sex on the Bench: Do Women Judges Matter to the Legitimacy of International Courts?' (2012) 12 Chicago Journal of International Law 647

33 “'Gassed” by John Singer Sargent', The Guardian (London 13 November 2008). 
Guernica, a twentieth-century art icon, ${ }^{34}$ depicts the effects of the bombing of the Basque town of Guernica by the German air force in 1937, during the Spanish Civil War of 1936-1939. ${ }^{35}$ Like other visual depictions of war crimes, the great painting constitutes a powerful anti-war protest ${ }^{36}$ and indirectly contributes to fostering a culture of peace.

Fifth, material culture in general and the visual arts in particular can play a role in international dispute settlement. Material culture can document and provide evidence of historical events of international relevance. ${ }^{37}$ It can also constitute the object (petitum) or the reason underlying a claimant's cause of action (causa petend $\imath$ ) of given international law disputes. ${ }^{38}$

Although the interplay between material culture and international law as a field of study is a rich and promising one, international lawyers engage insufficiently with the material traces and forms of law. Only recently have they started dealing with material culture. ${ }^{39}$ Some have foregrounded material culture for theoretical purposes. ${ }^{40}$ Others have focused on the promising emerging area of international cultural law. ${ }^{41}$ Material culture has also been used as evidence or for procedural purposes.

This section has briefly shown that such interplay constitutes a rich field for analysis. Not only has international law inspired some artists, but material culture has interacted with international law in a variety of ways. First, material culture can make international law accessible to a wide audience. Second, material culture can contribute to the teaching and dissemination of international law. Third, material culture can illuminate the current trajectories, promises and pitfalls of international law. Fourth, it can contribute to building a culture of peace that is one of the fundamental purposes of international law. Finally, material culture can play a role in international dispute settlement constituting evidence of historical events of international relevance or constituting the object (petitum) or reason underlying an international dispute (causa petendi).

\section{The pitfalls of using material culture}

There are some research limitations associated with using material culture in the international legal discourse. First, international law as a discipline and material culture studies often do not speak to each other. The implicit assumption seems to be that the different branches of learning are separate. The object of study of international legal

34 John Corbin, 'Images of War: Picasso's Guernica' (2010) 13 Visual Anthropology 1-21.

35 Ibid 1.

36 Ibid 2.

37 Pia F Cuneo, 'Introduction' in Pia F Cuneo (ed), Artful Armies, Beautiful Battles (Brill 2002) 3, 4.

38 See e.g. Nout Van Woudenberg, State Immunity and Cultural Objects on Loan (Brill 2012).

39 See e.g. Luis Eslava, Local Space Global Life (Cambrdige University Press 2015); Annelise Riles, 'Models and Documents: Notes on Some Artifacts of International Legal Knowledge' (1999) 48 International Comparative Law Quarterly 809-25.

40 International lawyers have analogised the debate on the functioning of international courts and tribunals to some architectural debates. For a seminal study, mutatis mutandis, see Dinah Shelton, 'Form, Function, and the Powers of International Courts' (2009) 9 Chicago Journal of International Law 537, 537 (on the debate raised by the construction of the first skyscrapers in Chicago); Eyal Benvenisti, 'Sovereigns as Trustees of Humanity: On the Accountability of States to Foreign Stakeholders' (2013) 107 American Journal of International Law 295, 295 and 298 (analogising the international community to 'a global condominium' and state sovereignty to 'a small apartment in one densely packed high-rise'); Valentina Vadi, Proportionality, Reasonableness and Standards of Review in International Investment Law and Arbitration (Edward Elgar forthcoming 2018) (analogising treaty-makers to city planners and arbitrators to architects and engineers).

41 See, ex multis, Hilary Charlesworth, 'Human Rights and the UNESCO Memory of the World Programme' in Michele Langfield, William Logan and Mairead Nic Craith (ed), Cultural Diversity, Heritage and Human Rights: Intersections in Theory and Practice (Routledge 2010) 21-30. 
scholarship is international law that aims at governing the relations among nations and promoting justice, peace and prosperity. Material culture studies' aims and objectives include developing ideas and representations through a range of varied techniques, materials and processes. While international law as a field of study has a normative nature, material culture empowers individuals to develop creativity. Both the discipline of international law and material culture studies foster critical thinking, but they do so using different languages and methods. The discipline of international law mainly relies on written languages, theories and practices, while material culture studies uses all of our senses. Particular orders of material objects, such as Grotius' book chest, have a specific relationship to the visual that, perhaps, texts do not have. International lawyers generally remain within the boundaries of the discipline and prefer linear, predefined and black letter approaches to questions. They do research in an individual, standardised and textdriven fashion. ${ }^{42}$ They predominantly relate to international law through written legal sources. ${ }^{43}$ They often 'feel that [written] texts are [their] major project and output'. ${ }^{44}$ International law books rarely contain images. ${ }^{45}$ When they do, international lawyers use images to illustrate a point; they rarely consider them as a source of information about international law. 46

This is not to say that international lawyers do not follow a certain aesthetics. In order to write persuasive legal arguments, international lawyers follow criteria of brevity, clarity and consistency and carefully select words, arguments and sources. Texts visually represent data and have visual aspects. Thus, international lawyers consciously make a series of informed choices about how to arrange their texts, including the font, margins and headings to be used. Material culture also increasingly appears on the covers of international law books. ${ }^{47}$ International lawyers, some scholars suggest, "use the cover page of their international law books, not only to illustrate their work but, more fundamentally, to attract the readers into a game'. ${ }^{48}$ In fact, the readers are invited to 'fin[d] an explanation for the cover of the book'. ${ }^{49}$

But even if some imagery has started to appear in international law works, there remains a traditional discomfort with material culture. Is there a traditional uneasiness of international law scholars with using images? Perhaps a religious legacy that the text is what really matters, and pictures are a distraction at best and a deviation at worst from the sacred text? The traditional separation between the discipline of international law and material culture studies does not mean that international lawyers should not be intellectually open.

42 Jessie Hohmann, 'Opium as an Object of International Law: Doctrines of Sovereignty and Intervention' in Cristina Binder, Mary E Footer and August Reinisch (eds), International Law and. . . Select Proceedings of the European Society of International Law (Hart 2014) 277, 277.

43 Ibid.

44 Ibid.

45 But see Ana Filipa Vrdoljak, International Law, Museums and the Return of Cultural Objects (Cambridge University Press 2006) ix (including a list of illustrations).

46 But see Katja Lubina, Contested Cultural Property: The Return of Nazi Spoliated Art and Human Remains from Public Collections (Maastricht 2009) back cover (showing the back of a painting, and noting, at 2, that 'stamps and stickers on the back of paintings often provide relevant information for the reconstruction of a painting's whereabouts during the years 1933-1945').

47 Jean D'Aspremont and Eric De Brabandere, 'The Paintings of International Law' in Jessie Hohmann and Daniel Joyce (eds), International Law's Objects (Oxford University Press forthcoming 2018) $<$ https://papers.ssrn.com/sol3/papers.cfm?abstract_id=2844136>.

48 Ibid 3.

49 Ibid. 
In turn, several academic disciplines such as art history and archaeology investigate objects and have developed distinctive methods and theoretical approaches. ${ }^{50}$ They study objects and consider them as an expression of a given civilization. They rely upon tangible artefacts, including diverse elements such as sculpture, crafts and so forth. Examining material culture unveils 'an entire cultural universe . . . in the object waiting to be discovered'. 51 Objects can be time capsules, which open new perspectives upon the past.

The traditional epistemic separation between the discipline of public international law and material culture studies raises the question as to whether interdisciplinary approaches can be envisaged, and, if so, whether they are desirable. International lawyers, archaeologists and art historians ask different questions when examining the same artefacts. They have different aims, objectives and methodologies. Therefore, questions arise as to whether methods of object analysis can and/or should migrate from one field to another. Moreover, without some methodological caution, there is a risk of epistemological misappropriation, as international lawyers are not trained in art appreciation, anthropology or archaeology.

Second, context matters. One should be cautious when interpreting material culture as historical evidence. ${ }^{52}$ In fact, one should try to understand given artefacts in the light of their historical, political and cultural context. As the art sociologist Arnold Hauser points out, 'artists always work in the midst of a social situation'. 53 One should ascertain whether artists had direct access to the given event; whether there were any artistic or ideological interventions on the part of the artist and/or his or her patron. ${ }^{54}$ Visual artefacts require critical engagement for becoming meaningful. ${ }^{55}$ Unavoidably, material culture does not merely reflect history, nor does it remain separate from politics. The artistic/political value can clash with the historical/legal value.

The same historical events can and have been visually rendered in diametrically opposite ways depending on the context in which the artist lived and worked. The French painter Jacques Louis David portrayed Napoleon as a military hero. As the painter of the imperial court, he completed several versions of Napoleon Crossing the Alps, depicting Napoleon riding an unruly horse in rather celebratory tones. ${ }^{56}$ From a completely different standpoint, Francisco Goya's The Disasters of War (Los Desastres de la Guerra), a series of 82 prints created between 1810 and 1820, depicted Napoleon's troops invading Spain. In this series, Goya took a 'radically new look at war'; 'where heroes have vanished and only human beings remain'. ${ }^{57}$ He painted how the Napoleonic War dramatically affected individual soldiers and civilians. Another Goya painting, The Third of May 1808 (El Tres de Mayo de 1808), completed in 1814, now in the Museo del Prado, Madrid, realistically depicts a prisoner soon to be shot in front of the firing squad.

Third, the cultural perspective of the interpreter needs to be considered. Since its creation, an object can give rise to different interpretations, depending on the 'cultural matrices' of the interpreters. ${ }^{58}$ Those international lawyers willing to engage with material

50 Prown (n 10) 7.

51 Ibid 6.

52 Cuneo (n 37) 3, 4.

53 Arnold Hauser, 'The “L'Art pour l'Art” Problem' (1979) 5 Critical Inquiry 426, 427.

54 Cuneo (n 37) 5.

55 Ibid.

56 Sarah Cokeley, 'Brushes with Conflict' (2015) 31 Military History 52-7.

57 Paul Bouvier, "Yo lo vi”. Goya Witnessing the Disasters of War' (2011) 93 International Review of the Red Cross 1107, 1133.

58 Prown (n 10) 6. 
culture to investigate their field are products of different cultural contexts. ${ }^{59}$ Can they step outside their own 'cultural givens' and 'interpret evidence objectively in terms of the beliefs of the individuals and the society that produced that evidence?'60 Arnold Hauser once argued that 'once we become aware of the problem [of perspective] we can struggle against subjectivity, against individual and class interests, and can move toward greater objectivity'. ${ }^{61}$ Both the discipline of international law and material culture studies embody some subjectivity. In fact, the process of interpretation is fraught by indeterminacy and craft matters as much as content.

Fourth, material culture studies cannot offer the sole, let alone the ultimate, lens of analysis of international law as a field of study. We cannot acquire complete access to international law through material culture alone. Rather, 'external information - that is, evidence drawn from outside the object . . p plays an essential role in the process'. ${ }^{62}$ Interdisciplinary methods can complement rather than supplant more traditional legal methods. ${ }^{63}$ In this regard, if a 'dialogue between methods' is to be promoted ${ }^{64}$ and international law scholars adopt approaches based on material culture studies, such methods should be part of a larger methodological tool kit. ${ }^{65}$

For instance, going back to the case study at the beginning of this article, Grotius' chest of books was a mere container of books. It does not indicate which books Grotius was reading in prison. Rather, it simply confirms that Grotius was reading lots of books during his imprisonment. The chest of books is a starting point for an in-depth analysis of material culture, written sources and historical context. In particular, Grotius' letters to his relatives shed light on the content of the book chest. Grotius' references also contribute to mapping his intellectual landscape. Investigating the historical period in which Grotius lived can provide additional elements to investigate his life and work. Therefore, using multiple methods is one way to address the complexity of international law.

Finally, in certain instances, the use of material culture can politicise the discipline of international law. As a legal system, international law aims at replacing power politics by providing a legal framework. Yet, it is often criticised for lacking teeth and the enforcement characteristic of domestic law'. ${ }^{66}$ Some international relations scholars even question whether international law is really law, or whether it rather reflects power politics. ${ }^{67}$ The character and effectiveness of international law remains contested in certain spheres. 68

Against this background, one may wonder whether any further politicisation of the field, driven by the use of material culture, can be self-defeating, pointless and even harmful. Material culture often does not offer a complete picture of events but a selective one. Therefore, at least in certain cases, it risks inserting a too high level of subjectivity

59 Ibid 4.

60 Ibid.

61 Arnold Hauser, 'Sociology of Art' in Berel Lang and Forrest Williams (eds), Marxism and Art: Writings in Aesthetics and Criticism (David McKay Co 1972) 272.

62 Prown (n 10) 6.

63 Woodward (n 13) 361.

64 Ibid.

65 Prown (n 10) 5.

66 Joyce (n 17) 232.

67 Ibid. See generally Martti Koskenniemi, 'The Politics of International Law' (1990) 1 European Journal of International Law 4-32; and, of the same author, 'The Politics of International Law: Twenty Years Later' (2009) 20 European Journal of International Law 7-19.

68 Joyce (n 17) 232. 
in international legal discourse. In such contexts, the use of material culture in international legal discourse would defeat the latter's aim of providing a legal rather than political stance. For instance, there is a risk that media coverage directs international legal responses; and that 'international legal agendas could come to depend too greatly on the priorities and biases of the media'. ${ }^{69}$ By emphasising the 'theatrical dimension of legal processes' there is a risk that the demands of international justice are subjected to a phenomenon known as 'trial by media'.70

The fact that there is a gap in the legal literature and that the interplay between international law as a field of study and material culture has not been properly addressed before may suggest that the issue is pointless or irrelevant. ${ }^{71}$ The fact that 'media coverage of conflict can ... contribute to the failure of [negotiations] and international legal responses in certain cases ${ }^{72}$ suggests that, in such cases, the use of material culture can be harmful. Media coverage can defeat diplomatic efforts and lead to the escalation of conflict. In sum, there are risks of 'simplification [and] amplification'. ${ }^{73}$

In conclusion, engaging with material culture presents some risks. The disciplines of international law and material culture studies have been traditionally perceived as separate branches of knowledge. The artistic and political value of material culture can clash with its historical and legal value. Material culture also risks further politicising international law.

\section{Critical assessment}

The traditional lack of reflection on the role of material culture in international law as a field of study does not necessarily correspond to lack of relevance; on the contrary, international law and material culture have interacted in a variety of ways for centuries. ${ }^{74}$ On the one hand, artists have long depicted events of international legal history for a variety of reasons, including artistic, documentary purposes and even (celebratory or critical) political reasons. Moreover, material culture studies have recently taken an 'international law turn'. ${ }^{75}$ The traditional dialogue between material culture and international legal phenomena has intensified.

On the other hand, international lawyers have become increasingly fascinated by material culture and the visual arts. In a 'visually driven era . . the visual dimension of law and the normative power of the image' have received increasing attention. ${ }^{76}$ 'International law has a rich existence in the world' and scholars have started investigating the relevance of given objects to international law. ${ }^{77}$ Investigating international law through the lenses of material culture demonstrates 'the centrality of international law to the lives [of people]', and illuminates 'the way international law penetrates and intervenes in multiple

69 Ibid

70 Ibid. 233

71 Sarah Nouwen, 'Scholarship in International Law: The Challenge of Relevance without Arrogance' European Society of International Law Newsletter (Florence June 2017) 3.

72 Joyce (n 17) 231.

73 Ibid 234.

74 See e.g. Jocelyn Penny Small, 'Time in Space: Narrative in Classical Art' (1999) 81 Art Bulletin 562, 562.

75 Eva Brems and Hilde Van Gelder, 'Engaged Visual Art as a Tool for Normative Renewal in International Human Rights', in Binder et al (n 42) ch 26.

76 Daniel Joyce and Gabrielle Simm, ‘Zero Dark Thirty: International Law, Torture and Representation’ (2015) 3 London Review of International Law 295, 295.

77 Hohmann (n 42) 277. 
aspects of each state's sovereignty'. ${ }^{78}$ For international lawyers, what matters is not the aesthetic quality of the object, but what that object 'says' about international law.

The interaction between material culture and international law takes place in different ways. Not only can material culture make international law open and accessible to a wide audience and have a didactic value, but it can illuminate the state of the art and the promises and pitfalls of the discipline. By depicting the dramatic effects of war, it can indirectly foster a culture of peace. The recognition that some forms of material culture constitute world heritage sites contributes to developing a sense of unity in diversity.

Material culture can be the object of international regulation and/or play a role in international dispute settlement. Given the growing expansion of international law, the discipline has increasingly governed elements of material culture from artworks to landscapes, from world heritage sites to cultural goods and the like. For instance, international cultural law is the branch of international law that governs different types of cultural heritage. By recognising the international public value of given cultural creations, international law can foster mutual understanding, dialogue and peace among civilisations, thus contributing to the prevention of war and the promotion of peaceful relations among nations. ${ }^{79}$ Other branches of international law have also dealt with aspects of material culture, from international criminal law to the law of the sea, from international economic law to climate change law.

Material culture can also play a role in international dispute settlement. ${ }^{80}$ Certain artefacts can have documentary value. Objects can portray a significant legal event, such as the signature of a treaty, the outbreak of a war, or the legal consequences of war. They can constitute evidence at trials before international courts and tribunals. ${ }^{81}$ They can also constitute object or reason underlying a claimant's cause of action. For instance, the theft, looting and destruction of cultural items during military conflicts have been subject to extensive debate in international law and furthered a number of international law responses, in the form of conventions, guidelines and high-profile disputes.

Third, material culture can also be 'a tool for normative renewal'. ${ }^{2}$ By portraying how international law works in practice, material culture can highlight areas for improvement of the discipline. Material culture can express criticism, nurture dissent and foster protest. This can spur adjustment, evolution and reform of critical areas of international law.

At the same time, engaging with material culture also presents some risks. The discipline of international law and material culture studies have been traditionally perceived as separate branches of knowledge. The artistic and political value of material culture can clash with its historical and legal value. Both material culture and international law require interpretation and this often implies a degree of subjectivity. Material culture risks enhancing the political aspects of international law.

In conclusion, material culture and international law have interacted in various ways. Despite some limits, material culture can provide an additional tool to conduct meaningful, fruitful and relevant research in international law.

78 Ibid 287.

79 Convention Concerning the Protection of the World Cultural and Natural Heritage (World Heritage Convention) 16 November 1972, 11 ILM 1358.

80 See, generally, V Vadi and H Schneider (eds), Art, Cultural Heritage and the Market: Ethical and Legal Issues (Springer 2014) 1-26.

81 Joyce and Simm (n 76) 295.

82 Brems and Van Gelder (n 75). 


\section{Conclusion}

Hugo Grotius' chest of books has no aesthetic merit, but it does have a significant relevance for (the history of) international law. Not only does it epitomise the escape of the great scholar and his quest for freedom, but it also narrates a gripping tale of derringdo and heroic courage. It also contributes to unveil Grotius' reliance on a number of previous scholars. The chest shows that the origins of international law are more pluralist than we are used to think. It also shows that material culture matters to international law and can contribute to its study in a significant way.

International lawyers have increasingly engaged with material culture. The interaction between material culture and international law takes place in different ways. Material culture can be the object of international regulation and/or international dispute settlement. Material culture can be a fruitful tool of research complementing traditional tools of legal research. It can also be a tool for normative renewal. Studying the linkage between the discipline of international law and material culture studies has the potential to defragment knowledge and overcome disciplinary boundaries. It has the potential to make international law more accessible across disciplines and among academic and other interested audiences.

At the same time, the use of material culture also presents some risks, such as that of politicising international law. While some politicisation is not necessarily a bad thing in the sense that it can be an opportunity for improvement, change and evolution, in some cases such politicisation can be self-defeating, pointless and even harmful. There is a risk that media exposure delays processes of peace, or presents only a selection of the relevant facts, thus jeopardising the proper functioning of international law and its dispute settlement mechanisms. But this is not to say that material culture is or should not be relevant to international legal discourse.

The linkage between international law and material culture is high risk and high gain: the fact that international law is often perceived as non-law highlights its fluidity and its evolution by trial and error. In this regard, some careful interaction between international law and material culture can help the former develop intellectual openness, overcome disciplinary boundaries, and raise new relevant questions. International lawyers are well trained in retrieving information in written texts, but have traditionally only marginally dealt with interpreting information encoded in objects. Yet, material culture can constitute a fruitful tool for investigating international law. At the same time, international lawyers should be aware of the fact that material culture presents a number of risks. Certainly, the relationship between international law and material culture deserves further study. 